\title{
Evaluasi K-3 Dalam Pencegahan Kecelakaan dari Penyakit Nosokomial Tenaga Kerja Kesehatan
}

\author{
Gempur Santoso \\ Guru Besar bidang Ergonomi-Keselamatan dan Kesehatan Kerja \\ Teknik Industri Universitas PGRI Adi Buana Surabaya. \\ Email: gempur_bohar@yahoo.com
}

\begin{abstract}
Abstrak: Keadaan saat ini, kejadian terjakit nosokomial masih mewabah. Resiko paparan nosokomial terutama adalah pada tenaga kerja (petugas) kesehatan. Secara deskriptif angka kejadian infeksi nosokomial tercatat di berbagai negara sekitar 3,3\%-9,2\%. Dari analisis data deskriptif dapat disimpulkan bahwa dalam pencegahan penyakit nosokomial harus mengontrol pasien sebagai sumber penyakit, peralatan kesehatan, peralatan petugas kesehatan, dan mensterilisasi peralatan serta lingkungan tempat kerja.
\end{abstract}

Nosokomial merupakan infeksi akibat layanan kesehatan maupun peralatan atau fasilitas layanan kesehatan. Infeksi ini bersifat latten akibat mokroarganisme di rumah sakit dan berbagai tempat layanan kesehatan. Hal itu perlu tindakan pencegahan (preventive) agar terbebas dari infeksi nosokomial. Sampai saat ini infeksi nosokomial kurang menjadi perhatian.

Menurut WHO, sekitar 8.7\% penderita yang dirawat di rumah sakit mengalami infeksi nosokomial rumah sakit. Sekitar 5-10\% penderita yang dirujuk ke bagian Intensive Care Unit-ICU rumah sakit atau fasilitas keperawatan, di negara United State Amerika (USA) saja dapat mencapai satu juta orang penderita setiap tahunnya (Sudarto, 2016). Kemudaian menurut Siti Marfu'ah, Liena Sofiana, (2018) mengatakan bahwa angka kejadian infeksi nosokomial tercatat di berbagai negara sekitar $3,3 \%-9,2 \%$.

Nosokomial harus dilakukan tindakan pecegahan, agar tidak semakin mewabah. Mikroorganisme yang berupa bakteri, virus, jamur, atau parasit ini bisa menjangkit pada pasien maupun petugas kesehatan. Mikroorganisme ini bisa berasal dari: dalam tubuh penderita sendiri (sumber endogin). Juga, sumber eksogin: lingkungan, perlengkapan rumah sakit yang tercemar, petugas rumah sakit, atau berasal dari penderita lain yang sedang dirawat di rumah sakit tersebut.

Sumber endogin adalah bagian tubuh yang biasanya menjadi tempat hidup koloni mikroorganisme, misalnya nasofaring, alat pencernaan atau saluran urogenital. Secara patologis, infeksi akan dimulai dari tempat masuknya mikoorganisme dan akan menimbulkan infeksi setempat (lokal) dan menimbulkan gejala klinis yang terbatas. Sebagaimana Suadarto (2016) mencontohkan bahwa luka operasi di perut yang mengalami infeksi, daerah sekitar luka akan menjadi merah, panas, dan nyeri. Infeksi umum akan terjadi jika organisme memasuki aliran darah dan akan menimbulkan gejala klinis sistemik, berupa demam, menggigil, penurunan tekanan darah, atau gangguan mental. Keadaan ini dapat berkembang menjadi sepsis (tubuh bereaksi hebat terhadap bakteria atau mikroorganisme), suatu keadaan yang berbahaya, karena menyerang berbagai organ dengan cepat dan bersifat progresif. Keadaan ini kadang-kadang disebut "keracunan darah" yang dapat menyebabkan kematian penderita. Sudarto (2016) juga menyebutkan bahwa infeksi nosokomial yang ditularkan melalui kateter ini menjadi penyebab 4-20\% kematian penderita.

Oleh karena itu, tidakan pencegahan yang merupakan yang merupakan hasil evaluasi dalam sistem manajemen likngkungan kerja perlu dilakukan. Ini merupakan tindakan perbaikan yang harus menjadi komitmen kua dalan organisasi atau tempat layanan kesehatan.

\section{METODOLOGI}

Pada tulisan ini, tujuan adalah pencegahan penyakit nosokomial di tempat layanan kesehatan. Rancangan tulisan adalah menguunakan deskriptif, yakni memaparkan keadaan penyakit nosokomial dan pecegahannnya. Analisis menggunakan deskriftif menggunakan literature yang terkait kejadian epidemiologis, patologis, pengendalian dan pencegahan nosokomial.

\section{SISTEM MANAJEMEN K-3 MENCEGAH NOSOKOMIAL}

Sesuai dengan Peraturan Menteri Tenaga Kerja nomor: 05/Men/96, terdapat 5 prinsip penerapan sistem manajemen keselamatan dan keslamatan kerja (SM K3). 5 prinsip tersebut, antara lain: 1) komitmen dan kebijakan, 2) perencanaan SMK3, 3) penerapan SMK3, 4) pengukuran dan evaluasi, serta 5) peninjauan ulang dan peningkatan oleh manajemen. Hasil peninjauan ulang tersebut sebagai peningkatan dan penyempunaan penerapan K3, harus menjadi komitmen dan kebijakan pihak menajemen. Tanpa komitmen dan kebijakan pihak manajemen, K3 tidak dapat diterapkan secara sempurna.

Hasil epidemiologis sudah muncul terjadi adanya. Hal itu perlu dicegah. Tanpa komitmen dan kebijakan pihak manajemen institusi untuk pencegahan nosokomial, sangat mungkin nosokomial semakin mewabah. 
Dalam Occupational Health and Safety Assesment Series (OHSAS) 18001:2007 dikutip Rendi Mahendra (2016) memberikan tips ketika merencanakan control atau pengendalian K3 secara hirarkis: 1) Eliminasi - memodifikasi desain untuk menghilangkan bahaya; misalnya, memperkenalkan perangkat mengangkat mekanik untuk menghilangkan penanganan bahaya manual; 2) Subtitusi - pengganti bahan kurang berbahaya atau mengurangi energi sistem (misalnya, menurunkan kekuatan, ampere, tekanan, suhu, dan lain-lain); 3) Kontrol teknik / Perancangan - menginstal sistem ventilasi, mesin penjagaan, interlock, dan lain-lain; 4) Kontrol administratif - tanda-tanda keselamatan, daerah berbahaya tanda, tanda-tanda fotoluminescent, tanda untuk trotoar pejalan kaki, peringatan sirene / lampu, alarm, prosedur keselamatan, inspeksi peralatan, kontrol akses, sistem yang aman, penandaan, dan izin kerja, dan lain-lain; 5) Alat Pelindung Diri (APD) - kacamata safety, perlindungan pendengaran, pelindung wajah, respirator, dan sarung tangan.

Dalam hal kontrol nosokomia. Eliminasi, misalkan memodifikasi tata letak tempat cuci tangan, dibuat praktis, mudah, dekat tempat memeriksa pasien, dan sebagainya. Substitusi, misalkan perlu ditemukan bahan kateter yang tidak mudah iritasi kulit, dan sebagainya. Kontrol teknik, setiap hari ruang/lingkunagn disemprot bahan untuk mesterilkan dari bakteri dan virus, dan sebagainya. Kontrol administrasi, misalkan dilakukan control secara berkala keadaan tempat tidur pasien, kontrol penggunaan antibiotik dan sebagainya. APD, misalkan petugas kesehatan harus selalu menggunakan baju kerja, masker, dan serung tangan.

Kemudian untuk pecegahan dan kontrol penyebaran nosokomial. Sebagaimana Soedarto (2016) menyarankan, sebagai berikut:

1. Isolasi penderita yang sudah diketahui penyebab infeksinya

2. Pengawasan dan pengendalian infeksi untuk setiap 200 tempat tidur

3. Identifikasi semua prosedur berisiko tinggi dan kemungkinan adanya sumber infeksi lainnya

4. Melaksanakan dengan tegas aturan untuk mencuci tangan bagi petugas kesehatan dan pengunjung untuk mencegah penularan mikroorganisme ke penderita atau penularan antar penderita yang dirawat

5. Melaksanakan dengan ketat pelaksanaan teknik aseptik pada semua prosedur termasuk penggunaan pakaian steril, sarung tangan, masker, dan alat pencegah penularan lainnya

6. Melakukan sterilisasi semua alat kesehatan yang digunakan ulang, misalnya ventilator, pelembab ruangan, dan semua hal yang berhubungan dengan saluran pernapasan

7. Mengganti sesering mungkin perban penutup luka dan memberikan salep antibiotik di bawah perban.

8. Lepaskan pipa nasogastrik dan endotrakeal sesegera mungkin sesudah tidak diperlukan lagi.

9. Menggunakan kateter vena yang sudah dibubuhi antibakteri untuk mencegah bakteri agar tidak dapat masuk ke dalam aliran darah .

10. Mencegah kontak petugas kesehatan dengan sekresi pernapasan dengan menggunakan pelindung, misalnya masker

11. Menggunakan kateter urine yang sudah dilapisi silver-alloy untuk mencegah bakteri menginfeksi kandung kemih

12. Kurangi penggunaan prosedur berisiko tinggi dan lama pemakaian alat-alat berisiko tinggi misalnya kateterisasi saluran kemih

13. Melakukan sterilisasi semua instrumen medis dan perlengkapan lainnya untuk mencegah kontaminasi.

14. Mengurangi penggunaan antibiotik secara berlebihan agar tidak menganggu sistem imun penderita dan mengurangi terjadinya resistensi bakteri.

Berdasarkan berbagai pendapat di atas, dapat disebutkan bahwa sumber nosokomial adalah dari pasien. Tenaga kerja (petugas) kesehatan mendapatkan paparan yang berisiko terkena penyakit nosokomial. Oleh karena itu, pasien harus dikontrol dalam penggunaan obat antibiotic tidak berlebihan. Jika terjangkit nosokomial maka pasien sebaiknya diisolasi, jika pasien luka maka perban penutup luka harus sering diganti dan sebaginya. Untuk petugas kesehatan, sebaiknya selalu mencuci tangan sebelum dan sesudah memeriksa pasien. Juga perlu kontrol terhadap peralatan dan lingkungan, misalkan sterilkan peralatan kesehatan, sterilasi lingkungan kerja, sterilisasi tempat tidur pasien, sehingga terindar micro-organism. Selain itu, penggunaan peralatan kesehatan harus mengikuti spesifikasi peralatan yang sesuai, serta sesuai prosedur penggunaan peralatan kesehatan.

\section{KESIMPULAN}

Berdasarkan analisis secara deskriftif di atas dapat disimpulan bahwa tindakan pecegahan kecelakaan dari penyakit nosokomial dilakukan kontrol terhadap pasien, tenaga kerja (petugas) kesehatan, peralatan kesehatan, prosedur penggunaan alat, sterilsasi peralatan kesehatan dan peralatan pasien dan petugas kesehatan, dan sterilsasi lingungan.

\section{DAFTAR PUSTAKA}

Peraturan Menteri Tenaga Kerja nomor: 05/Men/96, Model 5 prinsip penerapan SM-K3

Rendi Mahendra, 2016, Hierarki Pengendalian Bahaya dalam OHSAS 18001:2007, https://isoindonesiacenter.com/hierarki-pengendalianbahaya-dalam-ohsas-180012007/In "Training".

Soedarto, 2016, Infeksi Nosokomial Di Rumah Sakit, CV. Sagung Seto, Edisi, Pertama Jakarta 
3. Gempur Santoso - Evaluasi K-3 Dalam Pencegahan Kecelakaan ...

Siti Marfu'ah, Liena Sofiana, 2018, Analisis Tingkat Kepatuhan Hand Hygiene Perawat dalam Pencegahan Infeksi Nosokomial, e-mail: liena.sofiana@ikm.uad.ac.id Received: 16/12/2016; published: 16/01/2018, Jurnal Fakultas Kesehatan Masyarakat Volume 12, Issue 1, March 2018, pp. 29 37 ISSN: 1978 - 0575, Fakultas Kesehatan Masyarakat, Universitas Ahmad Dahlan, Yogyakarta 